\title{
Ethanol Causes Acute Inhibition of Carbohydrate, Fat, and Protein Oxidation and Insulin Resistance
}

John J. Shelmet, George A. Reichard,“ Charles L. Skutches,“ Robert D. Hoeldtke, Oliver E. Owen, and Guenther Boden Division of Diabetes/Metabolism, Department of Medicine, and General Clinical Research Center, Temple University Hospital, and ${ }^{*}$ Lankenau Medical Research Center, Philadelphia, Pennsylvania 19140

\begin{abstract}
To study the mechanism of the diabetogenic action of ethanol, ethanol $(0.75 \mathrm{~g} / \mathrm{kg}$ over $30 \mathrm{~min})$ and then glucose $(0.5 \mathrm{~g} / \mathrm{kg}$ over $5 \mathrm{~min}$ ) were infused intravenously into six normal males. During the 4-h study, 21.8 $\pm 2.1 \mathrm{~g}$ of ethanol was metabolized and oxidized to $\mathrm{CO}_{2}$ and $\mathrm{H}_{2} \mathrm{O}$. Ethanol decreased total body fat oxidation by $79 \%$ and protein oxidation by $39 \%$, and almost completely abolished the $249 \%$ rise in carbohydrate (CHO) oxidation seen in controls after glucose infusion. Ethanol decreased the basal rate of glucose appearance $\left(G_{R_{a}}\right)$ by $30 \%$ and the basal rate of glucose disappearance $\left(G_{R d}\right)$ by $38 \%$, potentiated glucose-stimulated insulin release by $54 \%$, and had no effect on glucose tolerance. In hyperinsulinemic-euglycemic clamp studies, ethanol caused a 36\% decrease in glucose disposal. We conclude that ethanol was a preferred fuel preventing fat, and to lesser degrees, $\mathrm{CHO}$ and protein, from being oxidized. It also caused acute insulin resistance which was compensated for by hypersecretion of insulin.
\end{abstract}

\section{Introduction}

The effects of ethanol on carbohydrate (CHO) ${ }^{1}$ metabolism are complex. When given to individuals whose glycogen stores have been depleted by fasting, ethanol can lead to severe hypoglycemia primarily by reducing hepatic glucose production through inhibition of gluconeogenesis $(1,2)$. The effects of ethanol in fed individuals are less well understood. In numerous studies, using many different experimental protocols, ethanol pretreatment has been associated with diminished (3), improved $(4,5)$, or unchanged $(6,7)$ glucose tolerance. Moreover, several patients have been reported in whom ethanol abuse led to overt diabetes mellitus which disappeared with abstinence from alcohol $(8,9)$. The mechanism for this diabetogenic effect of ethanol remains unknown. Because of the existing confusion in this area and the potential clinical importance of the problem, we have investigated, in normal male subjects, the acute effects of ethanol on the metabolism of an intravenous glucose load. To this end, we have measured total

Address correspondence and reprint requests to Dr. Boden, Temple University Hospital, 3401 North Broad Street, Philadelphia, PA 19140.

Received for publication 29 September 1986 and in revised form 19 October 1987.

1. Abbreviations used in this paper: a-v, arteriovenous; $\mathrm{CHO}$, carbohydrate.

J. Clin. Invest.

(C) The American Society for Clinical Investigation, Inc.

0021-9738/88/04/1137/09 $\$ 2.00$

Volume 81, April 1988, 1137-1145 body $\mathrm{CHO}$, fat, and protein oxidation by indirect calorimetry, glucose appearance and disappearance from the extracellular space by $\left[3-{ }^{3} \mathrm{H}\right]$ glucose dilution analysis and glucose disposal under hyperinsulinemic-euglycemic conditions with the clamp technique.

\section{Methods}

\section{Subjects}

Fourteen healthy male medical students and hospital employees, age $23.4 \pm 0.8 \mathrm{yr}$ (range $21-29 \mathrm{yr}$ ), body weight $81.0 \pm 3.0 \mathrm{~kg}$ (range $70.5-108.0 \mathrm{~kg}$ ), and relative ideal body weight $105 \pm 2 \%$ (range 96-120\%), participated in four study protocols. None had a family history of diabetes or alcoholism, admitted to drinking more than six drinks per week, or had consumed ethanol during the $72 \mathrm{~h}$ prior to any study and none were taking any medications. Informed written consent was obtained from all after explanation of the nature, purpose, and potential risks of each study. All study protocols were approved by the Human Research Committee of Temple University. The studies were performed in the General Clinical Research Center of Temple University Hospital and began between 7 and 8 a.m. after an overnight fast. The subjects were studied while reclining in hospital beds.

\section{Study design}

Four study protocols were used.

Protocol 1: glucose infusion studies. Six subjects were studied twice in random order with and without ethanol. A minimum of 7-10 d was allowed between ethanol and control (saline) studies. Catheters were placed in peripheral veins in each arm. One line was used to infuse ethanol, saline, glucose, and radiolabeled substances. A second line, in the contralateral arm, was used for blood sampling and was kept patent by a slow infusion of normal saline. Ethanol and control studies were identical except for the substitution of normal saline for ethanol in control studies. After a 2-h baseline period (-120 to $0 \mathrm{~min}$ ), alcohol $(0.75 \mathrm{~g} / \mathrm{kg}$, USP, Abbott Laboratories, N. Chicago, IL) diluted in normal saline to make a $12.5 \%$ solution, was infused intravenously for 30 $\min (0-30 \mathrm{~min})$. Glucose $(0.5 \mathrm{~g} / \mathrm{kg})$ was infused intravenously for 5 min starting at $60 \mathrm{~min}$. Venous blood was collected for determination of plasma glucose concentration every $10 \mathrm{~min}$ for the next hour and at 30-min intervals thereafter. Venous blood samples for determination of insulin, glucagon, free fatty acids, norepinephrine, epinephrine, ethanol, acetate, and acetaldehyde concentrations were obtained at 15or 30-min intervals for $4 \mathrm{~h}$.

Ethanol was determined in aliquots of urine collected at $\sim 30$-min intervals. For estimation of breath ethanol excretion by gas chromatography, expired air was collected in glass flasks at 30-min intervals after ethanol administration as previously described for acetone (10). The gas chromatograph was equipped with a flame ionization detector and a $183 \times 2$-cm glass column packed with Carbopack c/0.1\% SP-10 (Supelco, Inc., Bellefonte, PA). Ethanol concentration was determined from peak areas by comparison with gaseous ethanol standards. Ethanol output was calculated from the breath ethanol concentration and the respiratory minute-volume measured with the Beckman Instruments Metabolic Cart (Palo Alto, CA). Respiratory gas exchange (indirect calorimetry) was determined at 30-min intervals with the Beckman Instruments Metabolic Measurement Cart as described (11). Col- 
lections of urine for nitrogen determinations, necessary for calculations of rates of protein oxidation, were made at 30-min intervals (when possible) throughout the study.

Protocol 2: glucose turnover studies. Protocol 2 was identical to protocol 1 except for a primed $(40 \mu \mathrm{Ci})$, continuous $(0.4 \mu \mathrm{Ci} / \mathrm{min})$ [3- $\left.{ }^{3} \mathrm{H}\right]$ glucose infusion (New England Nuclear, Boston, MA) which was given for $6 \mathrm{~h}(-120$ to $+240 \mathrm{~min})$. Four subjects were studied twice, in random order, with and without ethanol. $2 \mathrm{~h}(-120$ to $0 \mathrm{~min})$ were allowed for equilibration of $\left[3-{ }^{3} \mathrm{H}\right]$ glucose. Plasma glucose was isolated from blood drawn at $-30,-20,-10,0,30,60,70,80,90,105$, $120,150,180,210$, and $240 \mathrm{~min}$ for determination of $\left[3-{ }^{3} \mathrm{H}\right]$ glucose specific activity (sp act) as previously described (12). Rates of glucose appearance $\left(G_{R_{a}}\right)$ and glucose disappearance $\left(G_{R d}\right)$ were calculated for 30-min intervals using the equations of Steele et al. (13) for nonsteady-state conditions.

Protocol 3: $\left[{ }^{14} \mathrm{C}\right]$ ethanol oxidation studies. Six subjects participated in these studies. The objective was to determine the extent to which intravenously administered ethanol was completely oxidized to $\mathrm{CO}_{2}$ and $\mathrm{H}_{2} \mathrm{O}$ during the 4-h study. Infusions of ethanol and glucose were as described in protocol 1 except for the addition of $50 \mu \mathrm{Ci}$ of $\left[1-{ }^{14} \mathrm{C}\right]-$ ethanol (New England Nuclear, sp act $10.4 \mathrm{mCi} / \mathrm{mmol}$ ) to the ethanol (one subject received only $31 \mu \mathrm{Ci}$ of $\left[1-{ }^{14} \mathrm{C}\right]$ ethanol by mistake). A transparent plastic hood, tightly fitted around the neck with a soft collar, was placed over the subject's head. The expired air, mixed with room air, which was continuously ventilated through the hood (at 35 liter/min), was drawn from the hood and collected in Douglas bags at $30,50,70,90,120,150,180,210$, and $240 \mathrm{~min}$ after ethanol was administered (between 0 and $30 \mathrm{~min}$ ). Respiratory minute volumes and $\mathrm{CO}_{2}$ concentrations of expired air were obtained at each sampling period from the Beckman Instruments Metabolic Measurement Cart. ${ }^{14} \mathrm{CO}_{2} \mathrm{sp}$ act in the respiratory gas samples were determined within $6 \mathrm{~h}$ after collection using the method of Fredrickson and Ono (14). Preliminary studies with prepared air samples containing $\left[{ }^{14} \mathrm{C}\right]$ ethanol showed no contamination of the $\mathrm{CO}_{2}$ trap of the collection system. It has been shown that after infusion of $\left[1-{ }^{14} \mathrm{C}\right]$ ethanol the respiratory ${ }^{14} \mathrm{CO}_{2}$ sp act and the ${ }^{14} \mathrm{CO}_{2}$ output rise in form of an exponential curve approaching with time an asymptotic value in subjects in whom the bicarbonate pool was not primed with $\mathrm{NaH}^{14} \mathrm{CO}_{3}$ (four of six in this study). This is due to the slow exchange between the labeled $\mathrm{CO}_{2}$ originating from $\left[1-{ }^{14} \mathrm{C}\right]$ ethanol oxidation and the unlabeled body bicarbonate pool. The asymptotic value of the sp act of ${ }^{14} \mathrm{CO}_{2}$ represents the ideal situation in which the sp act of ${ }^{14} \mathrm{CO}_{2}$ in exhaled air and that of ${ }^{14} \mathrm{CO}_{2}$ arising from tissue oxidation are identical. Issekutz et al. (15) have studied the time course of equilibration of the two pools by infusing $\mathrm{NaH}^{14} \mathrm{CO}_{3}$ and have shown that sp act of ${ }^{14} \mathrm{CO}_{2}$ at any time, $t$, can be corrected to the ideal sp act ${ }^{14} \mathrm{CO}_{2}, t=\infty$ (15). We have used their data to correct $\mathrm{CO}_{2}$ sp act values of the four subjects. The corrected ${ }^{14} \mathrm{CO}_{2}$ sp act and the $\mathrm{CO}_{2}$ production rate were used to calculate ${ }^{14} \mathrm{CO}_{2}$ output in subjects $1-4$. In two additional subjects (5 and 6 ) the bicarbonate pool was primed with a bolus injection of $\mathrm{NaH}^{14} \mathrm{CO}_{3}$ $(0.096 \mu \mathrm{Ci} / \mathrm{kg})$ prior to the start of the ethanol infusion. Venous blood samples during this study were obtained at $0,30,45,60,70,90$, and every $30 \mathrm{~min}$ thereafter for ethanol determinations which were used to calculate rates of ethanol disappearance from plasma.

Protocol 4: hyperinsulinemic-euglycemic clamp studies. Six subjects were studied twice, in random order, with and without ethanol. A minimum of 1 wk was allowed between studies. Regular human insulin (Humulin R, Eli Lilly \& Co., Indianapolis, IN) was infused intravenously ( $1 \mathrm{mU} / \mathrm{kg}$ per $\mathrm{min})$ for $5 \mathrm{~h}$. Glucose concentrations were clamped at about $80 \mathrm{mg} / \mathrm{dl}$ by a feedback-controlled glucose infusion (Biostator, Ames Life Science Instruments, Elkhart, IN). Blood for the Biostator was continuously drawn from a superficial antecubital vein. $2 \mathrm{~h}(0-120 \mathrm{~min})$ were allowed for attainment of steady-state hyperinsulinemia. To assess effects of different concentrations, ethanol infusion rates were calculated to produce plasma ethanol concentrations of $\sim 60$ and $120 \mathrm{mg} / \mathrm{dl}$. At $120 \mathrm{~min}$, ethanol $(0.375 \mathrm{~g} / \mathrm{kg})$ or saline was infused intravenously over a $15-\mathrm{min}$ period. Thereafter, an infusion of ethanol $(100 \mathrm{mg} / \mathrm{kg}$ per $\mathrm{h})$ or saline was delivered to maintain steady- state ethanol concentrations. At $210 \mathrm{~min}$ a second ethanol load of 0.5 $\mathrm{g} / \mathrm{kg}$ was administered over $30 \mathrm{~min}$ followed by the same maintenance infusion $(100 \mathrm{mg} / \mathrm{kg}$ per $\mathrm{h})$ until the completion of the study. Venous samples for determination of ethanol, insulin, glucagon, and free fatty acids were obtained at 0,30 , and every 15 min thereafter until completion of the studies. To determine whether it was necessary to obtain arterialized blood during euglycemic-hyperinsulinemic clamps we determined, in three separate studies, arteriovenous (a-v) glucose concentration differences during the basal and hyperinsulinemic phases of the clamps in blood collected simultaneously from a radial artery and a superficial antecubital vein. During euglycemic-euinsulinemic (insulin $9 \mu \mathrm{U} / \mathrm{ml}$ ) conditions glucose a-v differences were $+3,+7$, and $0 \mathrm{mg} / \mathrm{dl}$, respectively (mean $3.3 \mathrm{mg} / \mathrm{dl}$ ). During euglycemic-hyperinsulinemic (insulin $80 \mu \mathrm{U} / \mathrm{ml}$ ) conditions glucose a-v differences were $+6,+5$, and $+6 \mathrm{mg} / \mathrm{dl}$, respectively (mean $5.6 \mathrm{mg} / \mathrm{dl}$ ). Thus, a-v glucose differences were small during euinsulinemic and hyperinsulinemic euglycemia, which eliminated the need for collection of arterialized blood.

\section{In vitro insulin binding}

In vitro insulin binding was determined with primary cultures of rat hepatocytes prepared as previously described (16). Monolayers of hepatocytes $\left(\sim 2 \times 10^{6}\right.$ cells/flask) were preincubated in the absence or presence of ethanol in five different concentrations ranging from 100 to $1,000 \mathrm{mg} / \mathrm{dl}$ and with normal human serum (diluted 1:25) in MEM (final volume: $2.5 \mathrm{ml}$ ) at $37^{\circ} \mathrm{C}$ for $120 \mathrm{~min}$. After preincubation, the medium was aspirated and the cells washed twice with ice-cold KrebsRinger bicarbonate buffer ( $\mathrm{pH}$ 7.4). ${ }^{125} \mathrm{I}$-insulin binding was then determined as described (16). Interference of ethanol with ${ }^{125} \mathrm{I}$-insulin binding was assessed with cells not pre-incubated with ethanol but exposed to ethanol during the insulin binding assay.

\section{Analytic procedures}

Plasma glucose was measured with a Beckman Instruments glucose analyzer. Plasma insulin (17) and glucagon (18) were determined by radioimmunoassay. Plasma free fatty acids were measured according to Lorch and Gey (19) after extraction according to Dole and Meinertz (20). Plasma catecholamines were measured radioenzymatically (21). Plasma and urine ethanol were determined with a kit (Sigma Chemical Co., St. Louis, MO) as were blood acetate and acetaldehyde (Boehringer Mannheim, Elkhart, IN). For the determination of acetate and acetaldehyde (22) by enzymatic analysis, blood samples were immediately deproteinized and neutralized with perchloric acid/KOH and metaphosphoric acid/KOH, respectively, prior to assay.

\section{Statistical analysis and calculations}

All data are expressed as the mean \pm SEM. Statistical significance was assessed using MANOVA or Student's two-tailed paired $t$ test when appropriate.

\section{Ethanol disappearance and metabolism}

The rate of ethanol disappearance from the blood was calculated using the following formula: Ethanol disappearance $=B \times P \times \gamma$, where $B$ $=$ change in plasma ethanol concentration $(\mathrm{mg} / \mathrm{dl})$ obtained from the linear part of the plasma ethanol curve; $P=$ body weight $(\mathrm{kg}) \times 1.06$ to correct for differences in density between blood and water; and $\gamma$ = coefficient of distribution for ethanol (and acetate) (23).

Ethanol metabolism was determined according to the following formula: Ethanol metabolized = ethanol disappeared from blood - ethanol excreted in urine and breath - ethanol present in plasma as acetate.

\section{CHO, fat, and protein oxidation rates}

Respiratory quotients (RQ) were obtained from the computerized analysis of respiratory gas exchange by the Metabolic Measurement Cart as described (24). Based on our finding $\left(\left[{ }^{14} \mathrm{C}\right]\right.$ ethanol oxidation studies, protocol 3) of complete oxidation of ethanol to $\mathrm{CO}_{2}$ and $\mathrm{H}_{2} \mathrm{O}$ during the 4-h study, these respiratory exchange data were corrected by subtracting the volumes of $\mathrm{O}_{2}$ consumed and $\mathrm{CO}_{2}$ produced during 
ethanol oxidation (complete oxidation of 1 mol of ethanol consumes 3 mol of $\mathrm{O}_{2}$ and produces $2 \mathrm{~mol}$ of $\mathrm{CO}_{2}$ ). Protein oxidation rates were calculated from urinary nitrogen excretion and used to determine non-protein RQs. The ethanol-corrected non-protein RQs were then used to calculate $\mathrm{CHO}$ and fat oxidation rates as described previously (24).

\section{Results}

Effect of ethanol on glucose tolerance and insulin (Fig. 1). Infusion of ethanol $(0.75 \mathrm{~g} / \mathrm{kg}$ over $30 \mathrm{~min})$ during the glucose infusion studies (protocol 1) resulted in a peak concentration of $140 \pm 8 \mathrm{mg} / \mathrm{dl}$ at $30 \mathrm{~min}$. After equilibration (at $\sim 75 \mathrm{~min}$ ),

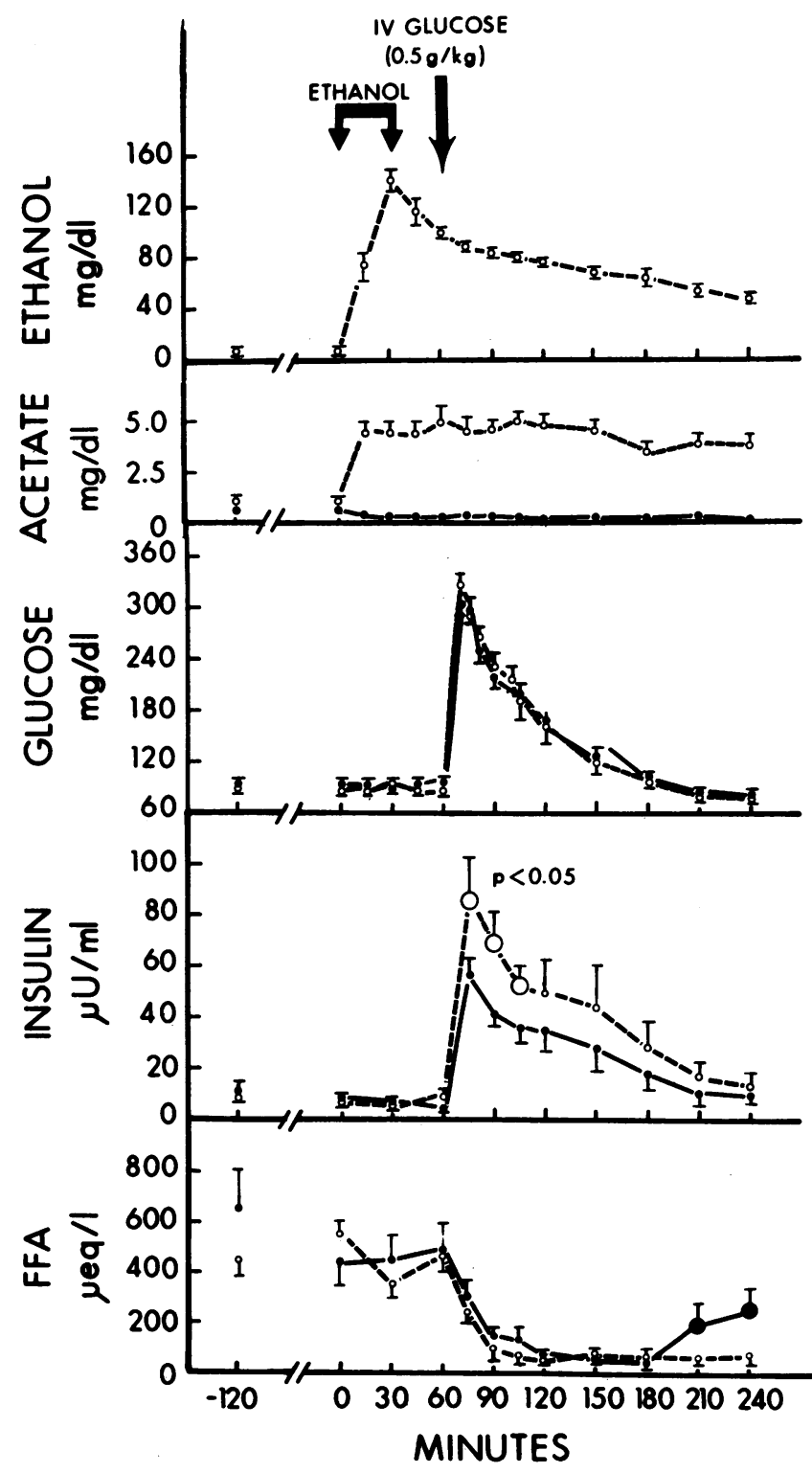

Figure 1. Effects of ethanol on glucose tolerance and insulin. Plasma concentrations of ethanol, acetate, glucose, insulin, and FFA after intravenous infusion of ethanol $(0.75 \mathrm{~g} / \mathrm{kg}$ from 0 to $30 \mathrm{~min}$, broken line and open circles) or saline (solid line and solid circles) and glucose $(0.5 \mathrm{~g} / \mathrm{kg}$ from 60 to $65 \mathrm{~min})$. Shown are mean \pm SEM. Large symbols indicate statistically significant differences between ethanol and saline studies. 1 , liter. $n=6$. ethanol concentrations declined at a constant rate and reached $48 \pm 5 \mathrm{mg} / \mathrm{dl}$ at $240 \mathrm{~min}$. These ethanol concentrations resulted in mild motor hyperactivity at the beginning and sleepiness during the later phases of the study in most subjects.

Blood acetate concentrations rose quickly after ethanol infusion to a peak of $4.7 \pm 0.4 \mathrm{mg} / \mathrm{dl}$ and remained elevated at about this level throughout the study. Acetaldehyde (not shown) was undetectable $(<0.008 \mathrm{mg} / \mathrm{ml})$ in peripheral venous blood in all subjects at the time of peak ethanol concentration ( $30 \mathrm{~min}$ ) and remained undetectable in five of six subjects at the end of the study in accordance with previously reported data (25).

Ethanol infusion had no significant effects on plasma glucose concentrations nor the rate of glucose disappearance from plasma after intravenous glucose.

Ethanol had no effect on basal, but significantly enhanced glucose-stimulated insulin concentrations between 70 and 105 min. For instance, at $70 \mathrm{~min}$, insulin concentrations with ethanol were $86 \pm 14 \mu \mathrm{U} / \mathrm{ml}$ compared with $56 \pm 8 \mu \mathrm{U} / \mathrm{ml}$ with saline $(P<0.05)$. The total 3 -h glucose-stimulated insulin response (area under the curve between 60 and $240 \mathrm{~min}$ ) was $54 \%$ greater with ethanol than with saline $(7,153 \pm 1,710$ vs. $\left.4,650 \pm 905 \mu \mathrm{U} / \mathrm{ml} \cdot \mathrm{min}^{-1}, P<0.025\right)$.

Plasma FFA concentrations were not significantly different in ethanol vs. control studies except during the last hour in which plasma FFA concentrations in the ethanol study remained suppressed, while those in the control study started to rise towards baseline levels. After glucose, FFA concentrations decreased precipitously from $480 \pm 121$ and $470 \pm 61 \mu \mathrm{eq} /$ liter at $60 \mathrm{~min}$ to $69 \pm 16$ and $46 \pm 17 \mu \mathrm{eq} / \mathrm{liter}$ at $120 \mathrm{~min}$ in control and ethanol studies, respectively $(P<0.01)$.

Counterregulatory hormones (Fig. 2). Except for transient and isolated increases in norepinephrine at $75 \mathrm{~min}$ and epinephrine at $30 \mathrm{~min}$, ethanol had no significant effects on plasma norepinephrine, epinephrine, or glucagon concentrations.

Oxidation of CHO, fat, and protein (Fig. 3). To assess possible effects of ethanol on intracellular substrate utilization, we measured $\mathrm{CHO}$, fat, and protein oxidation rates by indirect calorimetry. The use of this method in the presence of ethanol, was validated in the $\left[{ }^{14} \mathrm{C}\right]$ ethanol oxidation studies (vide infra).

Ethanol infusions had no significant effect on mean resting metabolic rates $\left(944 \pm 6\right.$ and $931 \pm 1 \mathrm{cal} / \mathrm{min}$ per $1.73 \mathrm{~m}^{2}$ in ethanol and control studies, respectively).

Basal ( -30 to $0 \mathrm{~min}$ ) rates of $\mathrm{CHO}$ oxidation were $40 \pm 5$ and $46 \pm 5 \mathrm{mg} / \mathrm{min}$ per $1.73 \mathrm{~m}^{2}$ in control and ethanol studies, respectively. Saline or ethanol infusions had no statistically significant effects on CHO oxidation. Glucose infusion in controls caused a $249 \%$ increase in $\mathrm{CHO}$ oxidation at $120 \mathrm{~min}$ (from $47 \pm 12$ to $117 \pm 11 \mathrm{mg} / \mathrm{min}$ per $1.73 \mathrm{~m}^{2}, P<0.025$ ). This glucose-stimulated increase was virtually abolished by ethanol and the total integrated above basal 3-h $\mathrm{CHO}$ oxidation was diminished by $80 \%$ (from $7.1 \pm 0.2$ to $1.4 \pm 0.2 \mathrm{~g}$ per $1.73 \mathrm{~m}^{2}, P$ $<0.05$ ).

Basal rates of fat oxidation in control and ethanol studies were similar $\left(69 \pm 8\right.$ and $72 \pm 5 \mathrm{mg} / \mathrm{min}$ per $\left.1.73 \mathrm{~m}^{2}\right)$. Ethanol infusion suppressed fat oxidation by $87 \%$ from $72 \pm 3$ (at $0 \mathrm{~min}$ ) to $9 \pm 3 \mathrm{mg} / \mathrm{min}$ per $1.73 \mathrm{~m}^{2}$ (at $\left.60 \mathrm{~min}\right)(P<0.001)$. Saline had no effect. After glucose infusion, fat oxidation decreased in controls in a reciprocal fashion to the increase in CHO oxidation (from $60 \pm 10$ to $32 \pm 6 \mathrm{mg} / \mathrm{min}$ per $1.73 \mathrm{~m}^{2}$ ) and then rose toward basal values. In ethanol studies after glucose infusion, 


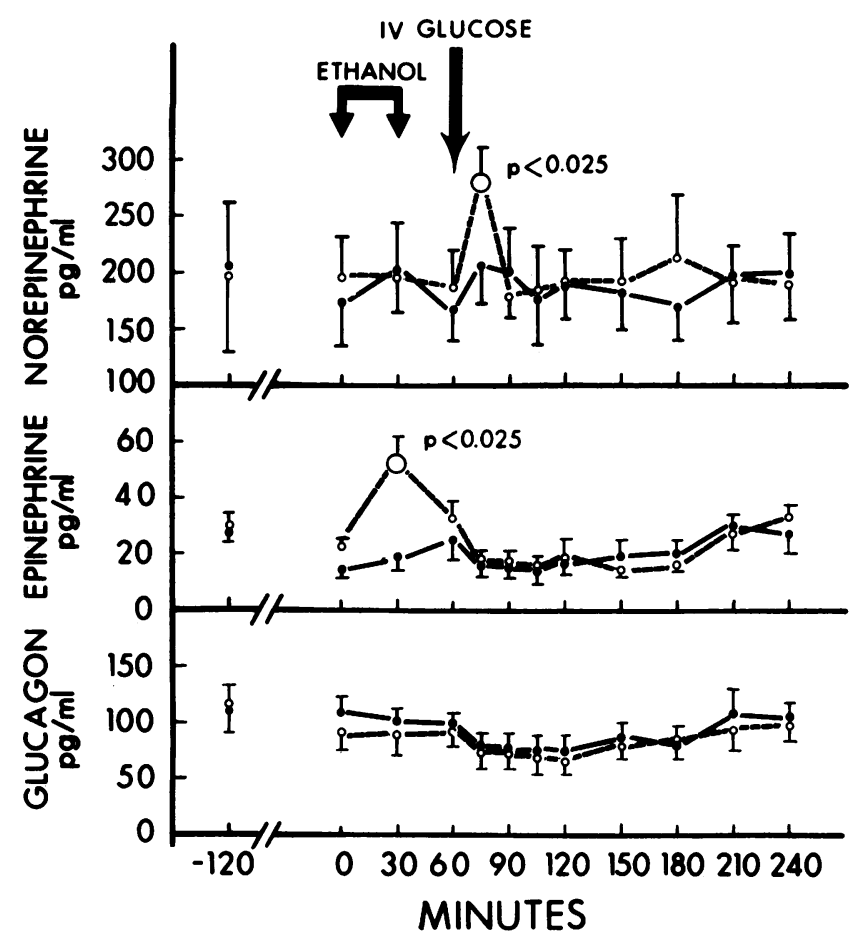

Figure 2. Effects of ethanol on counterregulatory hormones. Plasma concentrations of norepinephrine, epinephrine and glucagon after intravenous infusion of ethanol (or saline) and glucose. $n=6$. Symbols are as in Fig. 1.

fat oxidation rates decreased further to almost $0 \mathrm{mg} / \mathrm{min}$ per $1.73 \mathrm{~m}^{2}$ at $150 \mathrm{~min}$ and then rose slowly to $11 \pm 4 \mathrm{mg} / \mathrm{min}$ per $1.73 \mathrm{~m}^{2}$ at $240 \mathrm{~min}$. Ethanol decreased total integrated 4-h fat oxidation by $79 \%$ (from $12.0 \pm 1.8$ to $2.5 \pm 0.2 \mathrm{~g} / 1.73 \mathrm{~m}^{2}, P$ $<0.0025$ ).

Basal protein oxidation rates were similar in control and ethanol studies $\left(45 \pm 4\right.$ and $39 \pm 6 \mathrm{mg} / \mathrm{min}$ per $\left.1.73 \mathrm{~m}^{2}\right)$. In controls protein oxidation rates did not change during saline or glucose infusions. In response to ethanol it decreased from $41 \pm 5$ (at $0 \mathrm{~min}$ ) to $24 \pm 6 \mathrm{mg} / \mathrm{min}$ per $1.73 \mathrm{~m}^{2}$ (at $90 \mathrm{~min}, P$ $<0.005$ ). Ethanol decreased total integrated 4-h protein oxidation by $39 \%$ (from $11.0 \pm 0.7$ to $6.7 \pm 1.2 \mathrm{~g}$ per $1.73 \mathrm{~m}^{2}, P$ $<0.025$ ).

Ethanol metabolism and oxidation (Table I and Fig. 4). Ethanol $(59.5 \pm 1.8 \mathrm{~g})$ containing $\left[1-{ }^{14} \mathrm{C}\right]$ ethanol $(46.8 \pm 2.9 \mu \mathrm{Ci})$ was infused into six subjects and the exhaled $\mathrm{CO}_{2}$ was collected quantitatively (protocol 3). During the 4-h study, 25.97 $\pm 2.1 \mathrm{~g}$ of ethanol disappeared from the blood. Combined excretion of ethanol in urine and breath was $1.23 \pm 0.1 \mathrm{~g}$, and $1.88 \pm 0.2 \mathrm{~g}$ of ethanol remained in the blood as acetate. Thus, the amount of ethanol that was metabolized (ethanol disappeared from blood - ethanol excreted - ethanol remaining in blood as acetate) was $21.8 \pm 2.1 \mathrm{~g} / 4 \mathrm{~h}$ or $36.4 \pm 3.0 \%$ of the administered dose. Acetaldehyde was not considered in these calculations because of unmeasurably low blood concentrations in all subjects. This omission was inconsequential. Since acetaldehyde concentrations were $<0.008 \mathrm{mg} / \mathrm{ml}$ (the detection limit of our assay), $<0.44 \mathrm{~g}$ of ethanol was left in the blood as acetaldehyde, representing $<0.7 \%$ of the administered ethanol dose.

Fig. 4 shows the observed and corrected sp act of ${ }^{14} \mathrm{CO}_{2}$, which were used to calculate ${ }^{14} \mathrm{CO}_{2}$ production from $\left[1-{ }^{14} \mathrm{C}\right]-$

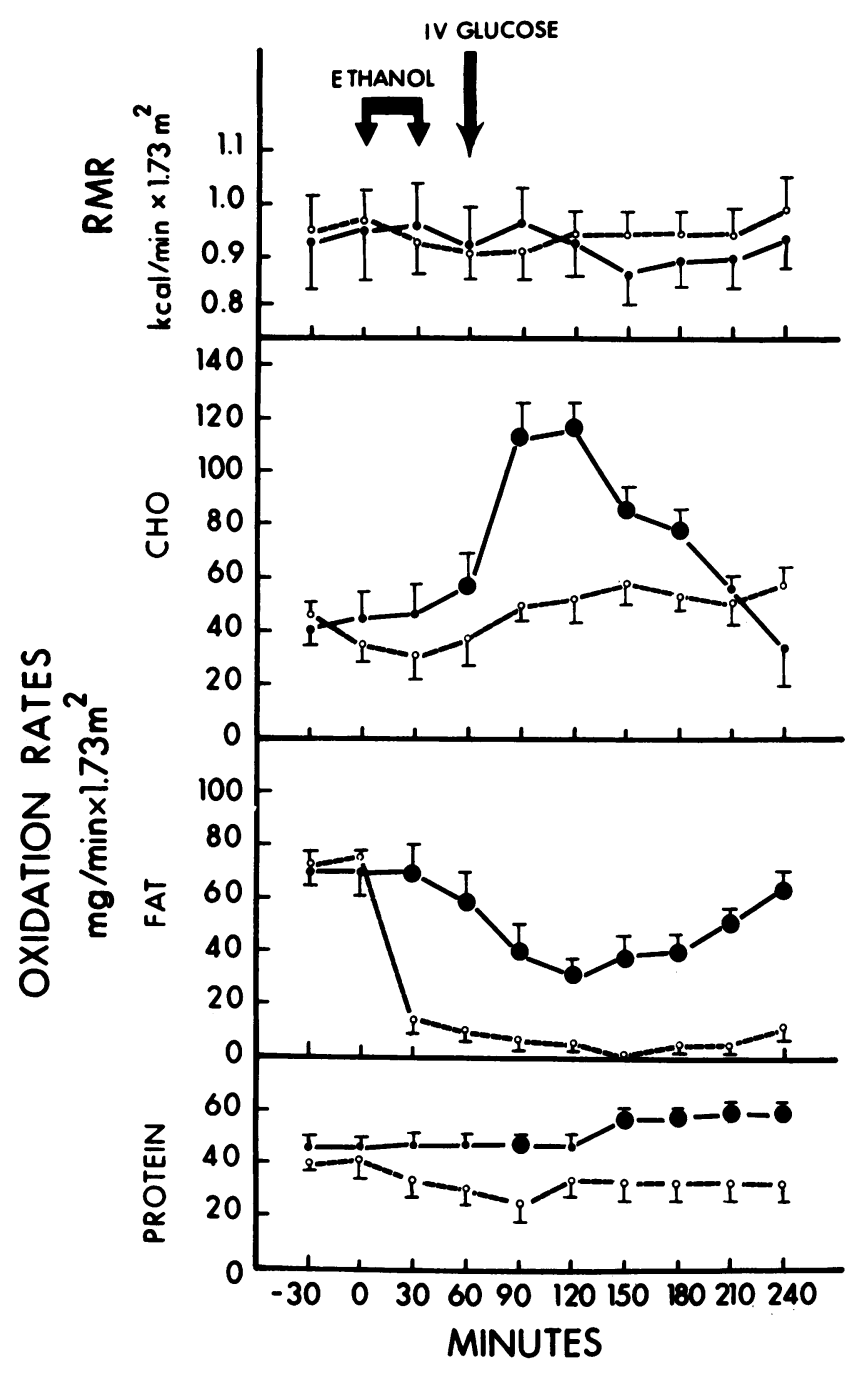

Figure 3. Effects of ethanol on resting metabolic rates $(R M R)$ and rates of $\mathrm{CHO}$, fat, and protein oxidation. Experimental design and symbols are as in Fig. 1. $n=6$.

ethanol in four of six subjects. In the two subjects whose bicarbonate pool was primed with $\mathrm{NaH}^{14} \mathrm{CO}_{3},{ }^{14} \mathrm{CO}_{2}$ sp act were stable throughout the studies $(6.3$ and $3.9 \mathrm{nCi} / \mathrm{mmol}$, respectively). Of the $46.8 \pm 2.9 \mu \mathrm{Ci}$ of $\left[1-{ }^{14} \mathrm{C}\right]$ ethanol infused, 17.5 $\pm 1.7 \mu \mathrm{Ci}$ or $37.2 \pm 2.3 \%$ were recovered as ${ }^{14} \mathrm{CO}_{2}$ and thus had been completely oxidized. Since about the same amount of nonradioactive ethanol was metabolized $(36.4 \pm 3.0 \%)$, essentially all of the ethanol which had been metabolized during the 4-h study was oxidized $(100.7 \pm 3.7 \%)$. These results made it possible to correct the indirect calorimetry data for ethanol oxidation and to calculate rates of $\mathrm{CHO}$ and fat oxidation.

Glucose turnover (Fig. 5, protocol 2). Basal rates ( 0 min) of glucose appearance $\left(G_{R a}\right)$ were similar in ethanol and control studies. Infusion of ethanol caused a $30 \%$ decrease in $\mathrm{G}_{\mathrm{Ra}}$ (from $2.4 \pm 0.2$ to $1.7 \pm 0.1 \mathrm{mg} / \mathrm{kg}$ per $\mathrm{min}, P<0.05$ ) while saline had no effect. Because of the reduced basal $G_{R a}$, peak total (endogenous + exogenous) $\mathrm{G}_{\mathrm{Ra}}$ at 90 min was also less in ethanol than in control studies $(8.7 \pm 0.7 \mathrm{vs.} 9.7 \pm 0.6 \mathrm{mg} / \mathrm{kg}$ per $\min , P<0.005)$ and remained lower than in controls until the end of the study. The total integrated 3-h glucose appearance 


\begin{tabular}{|c|c|c|c|c|c|c|c|c|c|c|c|}
\hline \multirow[b]{2}{*}{ Subjects } & \multirow{2}{*}{$\begin{array}{l}\text { Ethanol } \\
\text { infused }\end{array}$} & \multirow{2}{*}{$\begin{array}{l}\text { Ethanol* } \\
\text { disappeared } \\
\text { from blood }\end{array}$} & \multicolumn{2}{|c|}{ Ethanol excreted } & \multirow{2}{*}{$\begin{array}{l}\text { Ethanol } \\
\text { remaining } \\
\text { in blood } \\
\text { as acetate }\end{array}$} & \multirow{2}{*}{\multicolumn{2}{|c|}{$\begin{array}{c}\text { Ethanol } \\
\text { metabolized }\end{array}$}} & \multicolumn{3}{|c|}{$\left[1-{ }^{14} \mathrm{C}\right]$ ethanol } & \multirow{2}{*}{$\begin{array}{c}\text { Ethanol } \\
\text { Oxidized (\% of infused) } \\
\text { Metabolized (\% of infused) }\end{array}$} \\
\hline & & & Urine & Breath & & & & Infused & to ${ }^{14} \mathrm{CO}_{2}$ & & \\
\hline 1 & 64 & 35.54 & 0.916 & 0.193 & 2.67 & 31.76 & 49.6 & 50 & 22.5 & 45.0 & 0.907 \\
\hline 4 & 62 & 22.92 & 0.843 & 0.221 & 2.05 & 19.81 & 31.9 & 50 & 15.3 & 30.6 & 0.959 \\
\hline 5 & 58 & 20.90 & 0.917 & 0.195 & 0.794 & 18.99 & 32.7 & $50^{\S}$ & 15.5 & 31.0 & 0.948 \\
\hline 6 & 59 & 19.57 & 1.692 & 0.238 & 1.743 & 15.89 & 26.9 & $31^{8}$ & 10.5 & 33.8 & 1.092 \\
\hline Mean & 59.5 & 25.97 & 1.028 & 0.202 & 1.88 & 21.80 & 36.43 & 46.83 & 17.5 & 37.15 & 1.007 \\
\hline SEM & 1.8 & 2.1 & 0.138 & 0.012 & 0.23 & 2.10 & 2.98 & 2.89 & 1.7 & 2.3 & 0.037 \\
\hline
\end{tabular}

* Amount that has disappeared from blood between 0 and $240 \mathrm{~min}$ (including ethanol metabolized, excreted, and present as acetate). ${ }^{\ddagger}$ Equals ethanol disappeared minus ethanol excreted in urine and breath minus ethanol equivalents present in plasma as acetate at end of study. ${ }^{8 i-}$ carbonate pool was prelabeled with $\mathrm{NaH}^{14} \mathrm{CO}_{3}$ (see text for details).

(60-240 $\mathrm{min}$ ) was $24 \%$ less in ethanol than in control studies ( $515 \pm 25$ vs. $677 \pm 31 \mathrm{mg} / \mathrm{kg}, P<0.005$ ).

Basal rates of glucose disappearance $\left(G_{R d}\right)$ were similar in ethanol and control studies. Ethanol infusion suppressed $G_{R d}$ by $38 \%$ (from $2.20 \pm 0.4$ to $1.4 \pm 0.2 \mathrm{mg} / \mathrm{kg}$ per $\mathrm{min}, P<0.05$ ) while saline had no effect. $G_{R d}$ was lower in ethanol than in saline experiments during all except one time period (120 $\mathrm{min}$ ). The total integrated $3 \mathrm{~h}$ (60-240 $\mathrm{min}$ ) glucose disappearance in the presence of ethanol was $21 \%$ less compared with controls $(533 \pm 25$ vs. $677 \pm 30 \mathrm{mg} / \mathrm{kg}, P<0.005)$.

Effect of ethanol on glucose disposal (Fig. 6). Intravenous administration of a glucose load after ethanol infusion was associated with increased release of insulin but unchanged glucose tolerance (Fig. 1), suggesting acute onset of insulin resistance. To study the ethanol-induced insulin resistance in more detail, we performed hyperinsulinemic-euglycemic

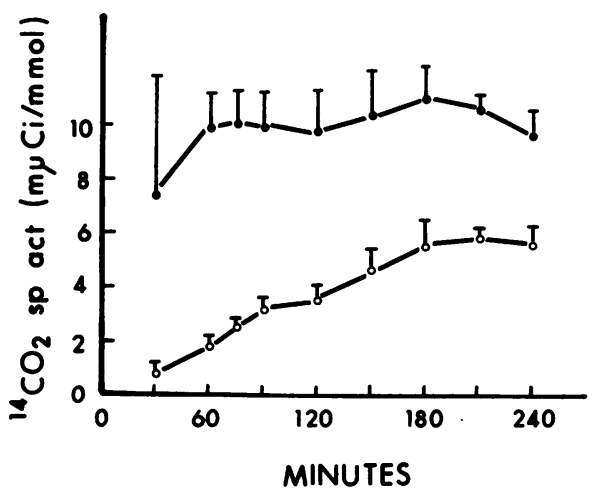

Figure 4. (Open circles) ${ }^{14} \mathrm{CO}_{2}$ sp act determined in four normal subjects after intravenous injection of $50 \mu \mathrm{Ci}$ of $\left[1-{ }^{14} \mathrm{C}\right]$ ethanol (protocol 3). (Solid circles) Corrected ${ }^{14} \mathrm{CO}_{2}$ sp act. The correction was done according to Issekutz et al. (15) and takes into account the slow exchange between the labeled $\mathrm{CO}_{2}$ originating from $\left[1-{ }^{14} \mathrm{C}\right]$ ethanol oxidation and the unlabeled body bicarbonate pool as well as the empirical fact that maximal ${ }^{14} \mathrm{CO}_{2}$ sp act does not exceed $80 \%$ of its theoretical value. clamp studies (protocol 4). Steady-state ethanol concentrations of $56 \pm 2 \mathrm{mg} / \mathrm{dl}$ were attained from 125 to $210 \mathrm{~min}$. The second ethanol bolus and maintenance infusion raised steadystate ethanol concentrations to $117 \pm 4 \mathrm{mg} / \mathrm{dl}$ during the last

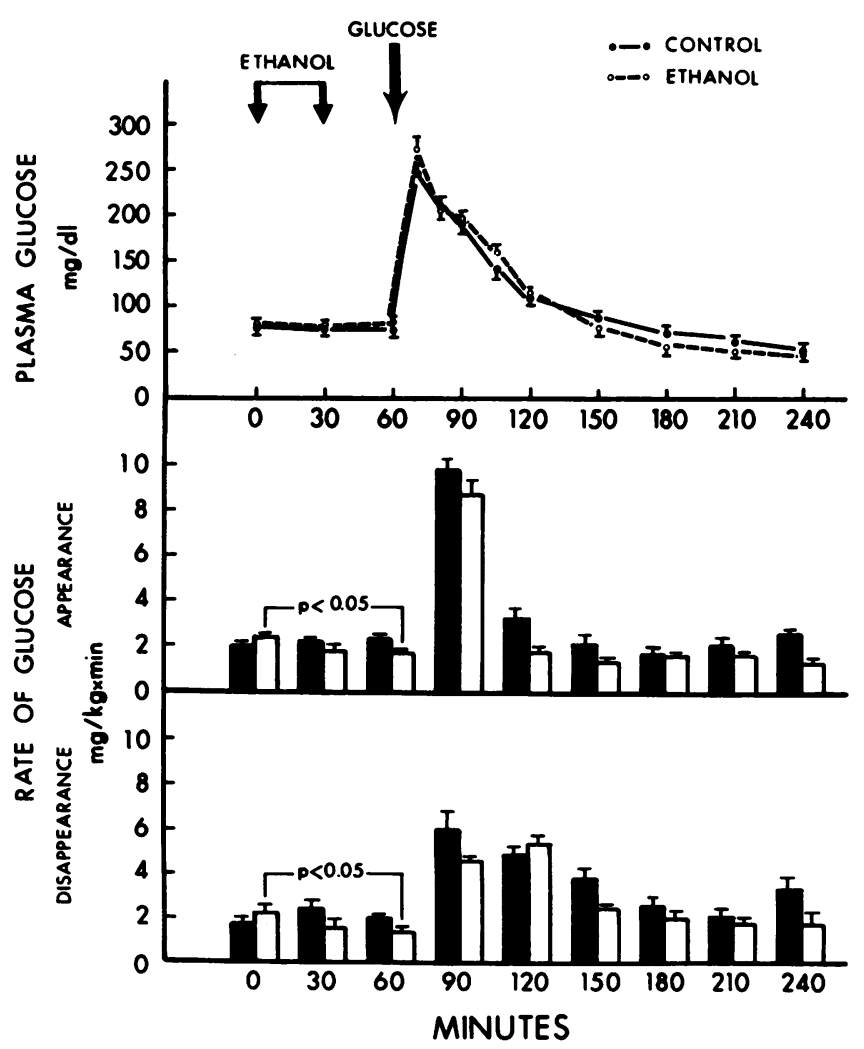

Figure 5. Effects of ethanol on glucose turnover. Plasma glucose and rates of glucose appearance and disappearance after intravenous infusion of ethanol (or saline) and glucose. Columns represent mean rates of glucose appearance or disappearance over 30 -min periods. Symbols are as in Fig. 1. $n=4$. 


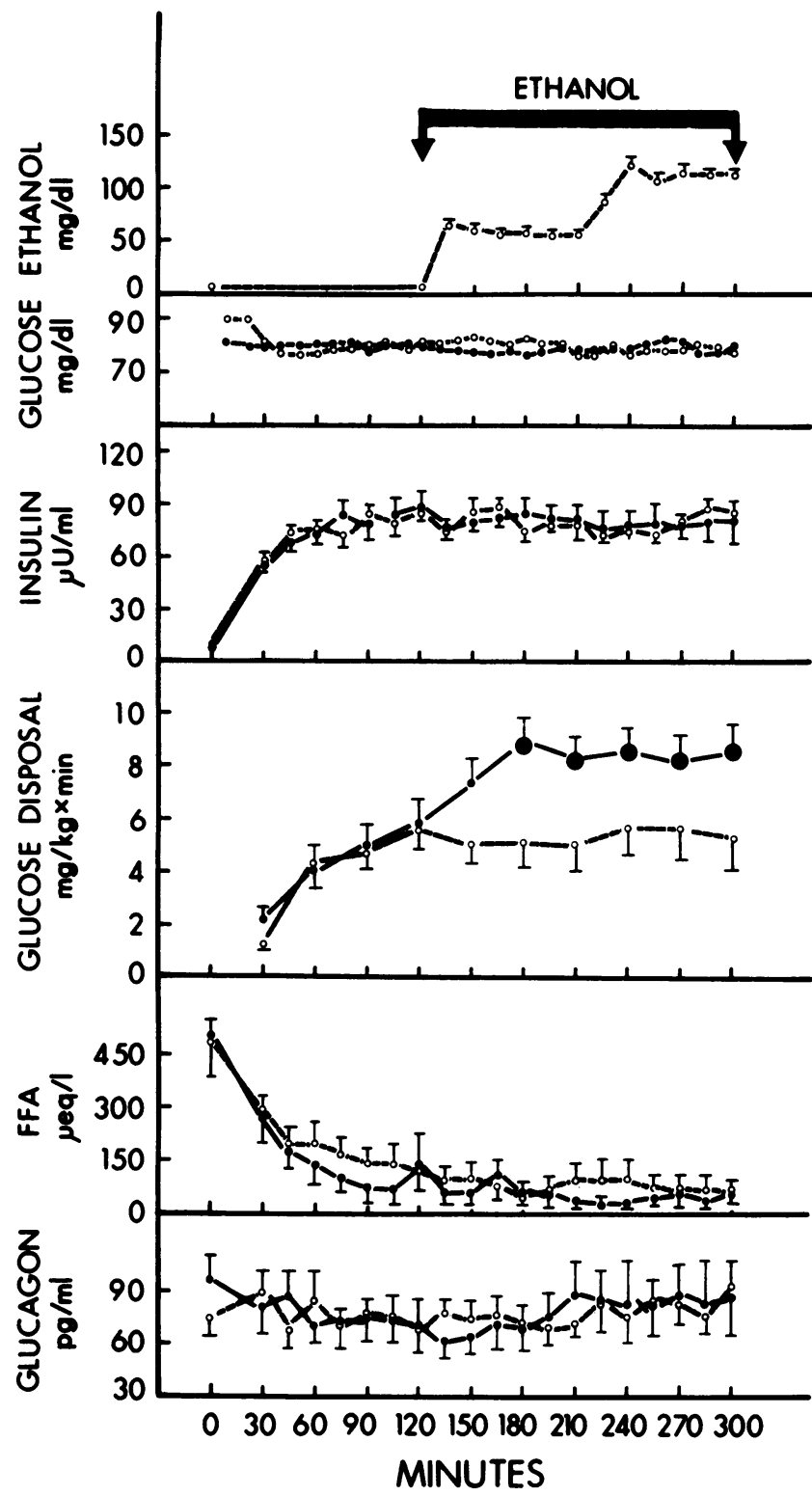

Figure 6. Effects of ethanol on glucose disposal during hyperinsulinemic-euglycemic clamps. Regular insulin ( $1 \mathrm{mU} / \mathrm{kg}$ per $\mathrm{min}$ ) was infused from 0 to $300 \mathrm{~min}$. Euglycemia was maintained by a variable, feedback-controlled glucose infusion. Glucose disposal represents the amount of glucose infused to maintain euglycemia. Ethanol was infused from 120 to $300 \mathrm{~min}$ (see text for details). Symbols are as in Fig. 1. 1, liter. $n=6$.

hour of the study. There was no difference in the effect of the two ethanol concentrations on glucose disposal nor on any of the other parameters measured. The most likely reason for this was that ethanol oxidation was maximal at the low ethanol concentration ( $\sim 56 \mathrm{mg} / \mathrm{dl}$ ) because of the low $K_{\mathrm{m}}$ of hepatic alcohol dehydrogenase (about $5 \mathrm{mg} / \mathrm{dl}$ ). It also suggested that the observed effects were not caused by ethanol itself, but probably by one or more of its metabolites. Plasma glucose concentrations were maintained at $80 \pm 0.4 \mathrm{mg} / \mathrm{dl}$ and $79 \pm 0.4$ $\mathrm{mg} / \mathrm{dl}$ in ethanol and control studies, respectively.

Plasma insulin concentrations rose from $9 \pm 1$ to $80 \pm 2$ $\mu \mathrm{U} / \mathrm{ml}$ in ethanol studies and from $8 \pm 1$ to $81 \pm 1 \mu \mathrm{U} / \mathrm{ml}$ in control studies as result of the insulin infusion $(1 \mathrm{mU} / \mathrm{kg}$ per $\mathrm{min}$ ). At these insulin concentrations, hepatic glucose production is known to be completely suppressed and the rate of glucose infused (by the Biostator) to maintain euglycemia equals the rate of glucose disposal, i.e., the amount of glucose leaving the extracellular glucose space (26). Since ethanol inhibited $G_{R a}$, it seemed reasonable to assume that hepatic glucose production remained completely suppressed during ethanol plus insulin infusions. Glucose disposal rates prior to ethanol were not significantly different in ethanol or control studies $(5.8 \pm 0.8$ vs. $5.9 \pm 0.9 \mathrm{mg} / \mathrm{kg}$ per $\mathrm{min}$ at $120 \mathrm{~min})$. In response to continued hyperinsulinemia, glucose disposal rates in the control studies rose from $5.8 \pm 0.8$ to a peak of $8.8 \pm 1.1$ $\mathrm{mg} / \mathrm{kg}$ per min and remained at about this level. This increase was completely abolished by ethanol which kept glucose disposal rates at about $5.7 \pm 1.1 \mathrm{mg} / \mathrm{kg}$ per min throughout. Integrated 3-h (120-300 $\mathrm{min})$ glucose disposal with ethanol was $947 \pm 132 \mathrm{mg} / \mathrm{kg}$ vs. $1,485 \pm 154 \mathrm{mg} / \mathrm{kg}$ with saline $(-36 \%, P$ $<0.02$ ).

Ethanol had no effects on free fatty acid or glucagon concentrations.

In vitro insulin binding. Specific insulin binding to cultured rat hepatocytes was $7.2 \pm 0.3 \%$ of the added trace $(n=19)$. No significant differences in specific binding were noted at any of the five ethanol concentrations (from 100 to $1,000 \mathrm{mg} / \mathrm{dl}$ ) studied. This was true regardless of whether cell cultures were preincubated in the presence of ethanol or whether ethanol was added to the ${ }^{125} \mathrm{I}$-insulin-binding assay mixture. Scatchard analysis of competitive insulin binding in the presence of 200 $\mathrm{mg} / \mathrm{dl}$ of ethanol showed no effect of ethanol on binding affinity or receptor number. There was also no effect of ethanol on tracer stability as evidence by TCA precipitability nor on hepatocyte viability as judged by trypan blue exclusion.

\section{Discussion}

The major findings in this study, namely the profound inhibitory effect of ethanol on the oxidation of other fuels, were obtained by indirect calorimetry. In order to use this technic in the presence of ethanol, it was necessary to demonstrate that all the ethanol, which had disappeared from the blood during the glucose infusion study $(24 \pm 2.9 \mathrm{~g})$ and was not excreted in urine or breath, nor remained in the body as acetate, had been completely oxidized to $\mathrm{CO}_{2}$ and water. This was accomplished in six subjects in whom ${ }^{14} \mathrm{CO}_{2}$ was collected quantitatively for $4 \mathrm{~h}$ after they received ethanol containing trace amounts of $\left[1-{ }^{14} \mathrm{C}\right]$ ethanol followed by intravenous glucose (protocol 3). The results showed that virtually all the ethanol which was metabolized was oxidized to $\mathrm{CO}_{2}$ and water (Table I). This allowed us to correct the respiratory quotients obtained by indirect calorimetry for the amounts of $\mathrm{O}_{2}$ consumed and $\mathrm{CO}_{2}$ generated from ethanol oxidation and to determine true $\mathrm{CHO}$ and fat oxidation rates.

To our knowledge, similar studies have not previously been performed in nonfasting human subjects. Bartlet and Barnet (27) have measured conversion of $\left[{ }^{14} \mathrm{C}\right]$ ethanol to ${ }^{14} \mathrm{CO}_{2}$ in pyruvate-treated rats. Similar to our results, they found that $\sim 40 \%$ of the administered radioactivity was recovered in expired $\mathrm{CO}_{2}$ within $4 \mathrm{~h}$. Recently, it has been reported that ethanol can be esterified with long chain fatty acids in certain organs including pancreas, liver, and heart (28). The 
quantities of ethanol metabolized through this non-oxidative pathway, however, appear to be too small ( $<1 \%$ of the oxidative pathway) to affect our calculations.

The dose of ethanol given in the glucose infusion studies (protocol 1) resulted in plasma ethanol concentrations ranging from $140 \pm 8 \mathrm{mg} / \mathrm{dl}$ (at the end of the ethanol infusion) to $48 \pm 5$ $\mathrm{mg} / \mathrm{dl}$ (at the end of the study). These concentrations permitted ethanol oxidation to proceed at a constant rate of $\sim 100$ $\mathrm{mg} / \mathrm{min}$ during the 4-h study ( $24 \mathrm{~g} / 4 \mathrm{~h}$, Table I) providing $\sim 710 \mathrm{cal} / \mathrm{min}$ or $61 \%$ of total metabolic requirements $(1,157 \pm 7 \mathrm{cal} / \mathrm{min})$. During the basal (pre-glucose) phase this resulted in an $87 \%$ decrease in fat oxidation (from 72 to 9 $\mathrm{mg} / \mathrm{min}$ per $1.73 \mathrm{~m}^{2}, P<0.001$ ) and a decline in its caloric contribution to the total metabolic rate from $\sim 70 \%$ to $<10 \%$. It is noteworthy, that plasma FFA concentrations, the substrate for fat oxidation, did not change during this time (see Fig. 1). During the basal period (0-60 min), ethanol had no statistically significant effects on $\mathrm{CHO}$ or protein oxidation. Possible reasons may have been the small contributions of $\mathrm{CHO}$ and protein oxidation to the total metabolic rate at that time (each contributed $<20 \%$ ); another, the relatively small number of subjects, which may have prevented the observed decreases in mean $\mathrm{CHO}$ and protein oxidation rates from reaching statistical significance.

After glucose infusion, ethanol oxidation continued unchanged, the already severely depressed fat oxidation decreased further, approaching $0 \mathrm{mg} / \mathrm{min}$ at $150 \mathrm{~min}$, and the $249 \%$ rise in CHO oxidation seen in controls (at $120 \mathrm{~min}$ ) was mostly abolished. Thus, ethanol appeared to act as a preferred fuel, almost totally replacing fat as substrate for oxidation during the basal period and preventing the large glucose load, which entered the intracellular space after intravenous glucose administration, from being oxidized. Our results are compatible with earlier work by others showing that ethanol inhibited oxidation of FFA and of alanine in rat liver (29-31). They also support the proposition by others that the ethanol induced inhibition of fat oxidation may play a role in the fatty infiltration of the liver that accompanies prolonged alcohol intake (for review see Lieber [32]). The cause for the preferred oxidation of ethanol was not investigated. It is known, however, that ethanol is quantitatively oxidized in the liver to acetate (33). Acetate is a common product of the metabolism of $\mathrm{CHO}$, fat, and some amino acids. It is readily activated to acetyl-coenzyme $A$ and promptly oxidized in the citric acid cycle $(34,35)$.

A quantitative assessment of the effect of ethanol on $\mathrm{CHO}$, fat, and protein oxidation has not been reported previously. Indirect calorimetry has been used to examine this question during the early part of this century (36-38). These investigators were unable to separate ethanol oxidation from the oxidation of other fuels and thus could not quantitate rates of $\mathrm{CHO}$, fat, and protein oxidation. Nevertheless, they observed a decrease in the respiratory quotient under the influence of ethanol which they interpreted as an indication that ethanol had replaced other substrates as fuel for oxidation.

In addition to its profound effects on fuel oxidation, ethanol also altered the rates at which glucose entered and disappeared from its extracellular space. During the basal period (0-60 min) ethanol depressed $G_{R a}$ by $30 \%$ (from $2.4 \pm 0.2$ to $1.7 \pm 0.1 \mathrm{mg} / \mathrm{kg}$ per $\mathrm{min}$ ) and $\mathrm{G}_{\mathrm{Rd}}$ by $38 \%$ (from $2.2 \pm 0.4$ to $1.4 \pm 0.2 \mathrm{mg} / \mathrm{kg}$ per $\mathrm{min}$ ). Since rates of appearance and disappearance were reduced similarly, there was no change in plasma glucose concentration.
After glucose infusion, ethanol caused a substantial increase in insulin release, as evidenced by an increase of $\sim 50 \%$ in the area under the plasma insulin concentration curve (Fig. 1). This suggested that there was an acute increase in insulin resistance, requiring additional insulin to maintain normal glucose tolerance. It is also possible that ethanol and/or its metabolites may have enhanced the stimulatory action of other insulin secretagogues. Ethanol-induced insulin resistance and inhibition of glucose transport were demonstrated unequivocally in the hyperinsulinemic-euglycemic clamp studies which showed a $36 \%$ reduction in glucose disposal. By sampling venous instead of arterial blood, we may have slightly overestimated the decrease in glucose disposal, if a-v glucose differences during the euglycemic-hyperinsulinemic clamps were substantially larger than the $6 \mathrm{mg} / \mathrm{dl}$ determined in three separate experiments (see Methods). The observation that ethanol-related changes in $\mathrm{CHO}$ oxidation and insulin secretion occurred simultaneously suggested, but did not prove, that these two phenomena may have been causally related. Ethanol has been shown to inhibit uridine diphosphate glucose-glycogen-transferase in rat diaphragm (39) and to inhibit glycogen synthesis in rat liver (40). Thus, it may inhibit not only oxidative but nonoxidative pathways for glucose utilization and result in a decrease in glucose transport.

Our findings of a decrease in the rate of glucose disappearance (glucose turnover studies) were in agreement with those of others. Kreisberg et al. (41) in the only other glucose turnover study in humans, reported that ethanol given orally to 12-h fasted normal subjects, resulting in blood ethanol concentrations ranging from 35 to $75 \mathrm{mg} / \mathrm{dl}$, did not change glucose tolerance but had a small $(\sim 10 \%)$ inhibitory effect on rates of glucose appearance and disappearance and markedly inhibited conversion of glucose to lactate. Lochner et al. (42) determined hepatic glucose output in 2-3-d fasted dogs by measuring arterial venous glucose concentration differences and found that ethanol (blood concentrations from 10 to 110 $\mathrm{mg} / \mathrm{dl}$ ) decreased glucose utilization by $25 \%$. Yki-Jarvinen and Nikkila (43) using the hyperinsulinemic-euglycemic clamp technic, found that ethanol reduced glucose disposal by $23 \%$. Clark and Evans (44) have shown that ethanol reduced glucose uptake by the isolated rat diaphragm. Lastly, potentiation of glucose mediated insulin release by ethanol has been reported by several investigators $(4,5,7)$.

In our studies, changes in plasma levels of counterregulatory hormones could not be incriminated as a cause for the decreased glucose utilization. Glucagon concentrations did not change in response to ethanol. The peak plasma epinephrine concentration after ethanol administration $(52 \mathrm{pg} / \mathrm{ml})$ was too low to significantly affect glucose metabolism (45). The ethanol effect on plasma norepinephrine (peak concentration $285 \mathrm{pg} / \mathrm{ml}$ ) may have reflected a physiologically significant activation of the sympathetic nervous system (46); however, whereas the ethanol effect on carbohydrate oxidation lasted for $2 \frac{1}{2} \mathrm{~h}$, the change in plasma norepinephrine was only transient ( $<30 \mathrm{~mm}$ ). Human growth hormone and cortisol were not measured because there is sufficient evidence in the literature to indicate that both hormones have no acute inhibitory effects on glucose utilization (47). It is therefore unlikely that human growth hormone or cortisol played a role in the development of insulin resistance which was seen within minutes after ethanol administration.

To investigate further the mechanisms by which ethanol 
could have inhibited glucose disposal, we assessed its effect on insulin binding to cultured rat hepatocytes in vitro. Ethanol has been reported to change adipocyte surface membrane fluidity (48) which conceivably could alter insulin binding and action. We found, however, that ethanol, even at very high concentrations (from 100 to $1,000 \mathrm{mg} / \mathrm{dl}$ ) did not influence insulin binding.

In conclusion, we have shown that under the conditions of this study, ethanol replaced fat as the predominant fuel for oxidation providing approximately two-thirds of basal caloric requirements. When an intravenous glucose load was given, ethanol prevented its oxidation. In addition, ethanol caused acute and comparable reductions in the rates of glucose appearance and disappearance. Ethanol did not alter glucose tolerance, because its diabetogenic effects on glucose disappearance and oxidation were counterbalanced by its potentiating action on glucose-stimulated insulin release and its reduction in hepatic glucose production $\left(\mathrm{G}_{\mathrm{Ra}}\right)$. These data suggest, that in individuals with impaired insulin secretory reserve, the net effect of ethanol may be a deterioration of glucose tolerance and may occasionally result in overt diabetes.

\section{Acknowledgments}

We thank Ms. Brenda Blyler and Ms. Lisa Panting for technical assistance, Ms. Marlene Mills for typing the manuscript, and Drs. R. Savage and Colleen Smith, Department of Biochemistry, for helpful discussions.

This study was supported by grants AM-36192, 5T32 AM-07162, AM-34548, and RR-349 from the U. S. Public Health Service and a grant from the Diabetes Research and Education Foundation.

\section{References}

1. Freinkel, N., D. L. Singer, R. A. Arky, S. J. Bleicher, J. B. Anderson, and C. K. Silbert. 1963. Alcohol hypoglycemia. I. Carbohydrate metabolism of patients with clinical alcohol hypoglycemia and the experimental reproduction of the syndrome with pure ethanol. $J$. Clin. Invest. 42:1112-1133.

2. Madison, L. L., A. Lochner, and J. Wulff. 1967. Ethanol-induced hypoglycemia. II. Mechanism of suppression of hepatic gluconeogenesis. Diabetes. 16:252-258.

3. Dornhorst, A., and A. Ouyang. 1971. Effect of alcohol on glucose tolerance. Lancet. ii:957-959.

4. McMonagle, J., and P. Felig. 1975. Effects of ethanol ingestion on glucose tolerance and insulin secretion in normal and diabetic subjects. Metab. Clin. Exp. 24:625-632.

5. Metz, R., S. Berger, and M. Mako. 1969. Potentiation of the plasma insulin response to glucose by prior administration of alcohol. Diabetes. 18:517-522.

6. Walsh, C. H., and D. J. O'Sullivan. 1974. Effect of moderate alcohol intake on control of diabetes. Diabetes. 23:440-442.

7. Nikkila, E. A., and M. R. Taskinen. 1975. Ethanol-induced alterations of glucose tolerance, postglucose hypoglycemia and insulin secretion in normal, obese, and diabetic subjects. Diabetes. 24:933943.

8. Phillips, G. B., and H. F. Safrit. 1971. Alcoholic diabetes. JAMA (J. Am. Med. Assoc.) 217:1513-1519.

9. Feingold, K. R., and M. D. Siperstein. 1983. Normalization of fasting blood glucose levels in insulin-requiring diabetes: The role of ethanol abstention. Diabetes Care. 6:186-188.

10. Reichard, G. Jr., A. C. Haff, C. L. Skutches, P. Paul, C. P. Holroyde, and O. E. Owen. 1979. Plasma acetone metabolism in the fasting human. J. Clin. Invest. 63:619-626.
11. Boden, G., T. K. Ray, R. H. Smith, and O. E. Owen. 1983. Carbohydrate oxidation and storage in obese non-insulin-dependent diabetic patients. Diabetes. 32:982-987.

12. Radziuk, J., K. H. Norwich, and M. Vranic. 1978. Experimental validation of measurements of glucose turnover in non-steady-state. Am. J. Physiol. 234:E84-93.

13. Steele, R., J. S. Wall, R. C. DeBodo, and N. Altszuler. 1956. Measurement of size and turnover rate of body glucose pool by the isotope dilution method. Am. J. Physiol. 187:15-24.

14. Fredrickson, D. S., and K. Ono. 1958. An improved technique for assay of $\mathrm{C}^{14} \mathrm{O}_{2}$ in expired air using the liquid scintillation counter. J. Lab. Clin. Med. 51:147-151.

15. Issekutz, B., Jr., P. Paul, H. I. Miller, and W. M. Bortz. 1968. Oxidation of plasma FFA in lean and obese humans. Metab. Clin. Exp. 71:62-73.

16. Shimoyama, R., T. K. Ray, C. R. Savage, Jr., O. E. Owen, and G. Boden. 1984. In vivo and in vitro effects of anti-insulin receptor antibodies. J. Clin. Endocrinol. Metab. 59:916-923.

17. Soeldner, J. S., and D. Slone. 1965. Critical variables in the radioimmunoassay of serum insulin using the double antibody technic. Diabetes. 14:771-779.

18. Faloona, G. R., and R. H. Unger. 1974. Glucagon. In Methods of Hormone Radioimmunoassay. B. M. Jaffe, and H. R. Behrman, editors. Academic Press, Inc., New York. 317-330.

19. Lorch, E., and K. F. Gey. 1966. Photometric "titration" of free fatty acids with the Technicon analyzer. Anal. Biochem. 16:244-252.

20. Dole, V. P., and H. Meinertz. 1960. Microdetermination of long-chain fatty acids in plasma and tissues. J. Biol. Chem. 235:25952599.

21. Passon, P. G., and J. D. Peuler. 1973. A simplified radiometric assay for plasma norepinephrine and epinephrine. Anal. Biochem. 51:618-631.

22. Lundquist F. 1974. Methods of Enzymatic Analysis. 2nd edition, Vol. 3. H. V. Bergmeyer, editor. Verlag Chemie, Weinheim. Academic Press, Inc., New York. 1509-1915.

23. Carpenter, T. M. 1940. The metabolism of alcohol: a review. Q. J. Stud. Alcohol. 1:201-226.

24. Owen, O. E., V. E. Trapp, G. A. Reichard, Jr., M. A. Mozzoli, R. Smith, and G. Boden. 1980. Effects of therapy on the nature and quantity of fuels oxidized during diabetic ketoacidosis. Diabetes. 29:365-372.

25. Nuutinen, H. U., M. P. Salaspuro, M. Valle, and K. O. Lindross. 1984. Blood acetaldehyde concentration gradient between hepatic and antecubital venous blood in ethanol-intoxicated alcoholics and controls. Eur. J. Clin. Invest. 14:306-311.

26. Rizza, R. A., L. J. Mandarino, J. E. Gerich. 1981. Dose-response characteristics for effects of insulin on production and utilization of glucose in man. Am. J. Physiol. 240:E630-639.

27. Bartlett, G. R., and H. N. Barnet. 1949. Some observations on alcohol metabolism with radioactive ethyl alcohol. $Q$. J. Stud. Alcohol. 10:381-397.

28. Laposata, E. A., and L. G. Lange. 1986. Presence of nonoxidative ethanol metabolism in human organs commonly damaged by ethanol abuse. Science (Wash. DC). 231:497-499.

29. Lieber, C. S., and R. Schmid. 1961. The effect of ethanol on fatty acid metabolism; stimulation of hepatic fatty acid synthesis in vitro. J. Clin. Invest. 40:394-399.

30. Reboucas, G., and K. J. Isselbacher. 1961. Studies on the pathogenesis of the ethanol-induced fatty liver. I. synthesis and oxidation of fatty acids by the liver. J. Clin. Invest. 40:1355-1362.

31. Freinkel, N., A. K. Cohen, R. A. Arky, and A. E. Foster. 1965. Alcohol hypoglycemia. II. A postulated mechanism of action based on experiments with rat liver slices. J. Clin. Endocrinol. 25:76-94.

32. Lieber, C. S. 1982. Ethanol and lipid disorders, including fatty liver, hyperlipemia and arterosclerosis. In Medical Disorders of Alcoholism: Pathogenesis and Treatment. L. H. Smith, editor. W. B. Saunders Co., Philadelphia. 141-177.

33. Lundquist, F., N. Tygstrup, K. Winkler, K. Mellemgaard, and 
S. Munck-Peterson. 1962. Ethanol metabolism and production of free acetate in the human liver. J. Clin. Invest. 41:955-961.

34. Skutches, C. L., C. P. Holroyde, R. N. Myers, P. Paul, and G. A. Reichard, Jr. 1979. Plasma acetate turnover and oxidation. J. Clin. Invest. 64:708-713.

35. Skutches, C. L., M. H. Sigler, B. P. Teehan, J. H. Cooper, and G. A. Reichard, Jr. 1983. Contribution of dialysate acetate to energy metabolism: metabolic implications. Kidney Int. 23:57-63.

36. Carpenter, T. M., and R. C. Lee. 1937. The effect of glucose on the metabolism of ethyl alcohol in man. J. Pharmacol. Exp. Ther. 60:264-285.

37. Togel, O., E. Brezina, and A. Durig. 1913. Über die kohlenhydratsparende Wirkung des Alkohols. Biochem. Z. 50:296-346.

38. Brechmann, H. J. 1925. Respirationsversuche nach Aufnahme von Fruchtzucker, Traubenzucker and Alkohol sowohl während der Ruhe als auch während der Arbeit. Biochem. Z. 83:448-466.

39. Williams, H. E. 1965. In vitro effects of ethanol on carbohydrate metabolism. Clin. Res. 13:336.

40. Field, J. B., H. B. Williams, and G. E. Mortimore. 1963. Studies on the mechanism of ethanol-induced hypoglycemia. J. Clin. Invest. 42:497-506.

41. Kreisberg, R. A., A. M. Siegal, and W. C. Owen. 1971. Glucose-lactate interrelationships: effect of ethanol. J. Clin. Invest. 50:175-185.
42. Lochner, A., J. Wulff, and L. L. Madison. 1967. Ethanol-induced hypoglycemia: the acute effects of ethanol on hepatic glucose output and peripheral glucose utilization in fasted dogs. Metab. Clin. Exp. 16:1-18.

43. Yki-Jarvinen, H., and E. A. Nikkila. 1985. Ethanol decreases glucose utilization in healthy man. J. Clin. Endocrinol. Metab. 61:941-945.

44. Clarke, D. W., and R. L. Evans. 1960. The influence of alcohol upon carbohydrate metabolism in the liver and in isolated diaphragms. Q. J. Stud. Alcohol. 21:13-22.

45. Clutter, W. E., D. M. Bier, S. D. Shah, and P. E. Cryer. 1980. Epinephrine plasma metabolic clearance rates and physiological thresholds for metabolic and hemodynamic actions in man. J. Clin. Invest. 66:94-101.

46. Silverberg, A. B., S. D. Shah, M. Haymond, and P. E. Cryer. 1978. Norepinephrine: hormone and neurotransmitter in man. Am. J. Physiol. 234:E252-E256.

47. Cryer, P. E., and J. E. Gerich. 1983. Relevance of glucose counterregulatory systems to patients with diabetes: critical roles of glucagon and epinephrine. Diabetes Care. 6:95-99.

48. Sauerheber, R. D., J. A. Esgate, and C. E. Kuhn. 1982. Alcohol inhibits adipocyte basal and insulin-stimulated glucose uptake and increase the membrane lipid fluidity. Biochim. Biophys. Acta. 691:115-124. 